\title{
GENEALOGIAS DA ESCRITA
}

As genealogias da escrita têm sido objeto de abordagens teórico-críticas e matéria de reflexão constante em ensaios, notas de trabalho e, muito especialmente, em diários de escritores. A sentença formalista segundo a qual a literatura não se movimenta em linha reta, de pai a filho, mas por caminhos oblíquos, de tio a sobrinho, a distinção estabelecida por Said entre filiação e afiliação, ou o convite, feito por Roland Barthes na Preparação do romance, a glisser [deslizar] uma linhagem são algumas das manifestações legíveis no domínio teórico-crítico. Os Diários de Emilio Renzi, publicados por Ricardo Piglia entre 2015 e 2017 são uma expressão privilegiada e recente desse laboratório do escritor, no qual se discutem tradições intelectuais, traçam-se ficções genealógicas e se revisitam com insistência os diários (laboratórios) de outros escritores.

O Dossiê deste número da revista Remate de Males reúne um conjunto de artigos sobre a dimensão genealógica e laboratorial de escritos de diversa procedência (literatura argentina, chilena, brasileira, italiana, norte-americana, letras francesas) e de distintas épocas (do século XIX à atualidade).

Os sete primeiros textos são produto de uma circunstância específica: o colóquio Leituras Cruzadas de Ricardo Piglia, realizado no Instituto de Estudos da Linguagem da Unicamp com o apoio do Programa de Pós-Graduação em Teoria e História Literária e do Observatório Latino-americano da Unicamp, nos dias 28 e 29 de maio de 2019. Participaram do evento e têm seus textos aqui publicados os professores, críticos e pesquisadores Martín Kohan, Pedro Meira Monteiro, Júlio Pimentel Pinto, Miriam Viviana Gárate, Gisela Bergonzoni, Kelvin Falcão Klein e Livia Grotto. Levando em conta o caráter retrospectivo e heterogêneo 
de toda genealogia (nas palavras de Foucault: enfatizando seu caráter de "emergência”, "conjurando a quimera da origem”), os artigos resultantes do colóquio exploram diversos aspectos dessa trilogia gigantesca e fragmentária, já parcialmente traduzida para o português, que vem suscitando um renovado interesse pelo conjunto da produção de Piglia.

"Diario diferido", de Martín Kohan, lê o gesto polêmico imprimido por Piglia à escrita retroativa de seus cadernos pessoais e o caráter "estrategicamente póstumo" dos Diários de Emilio Renzi. O artigo de Pedro Meira Monteiro, "O corpo desaparecido: a permanência da literatura em Ricardo Piglia”, indaga a busca do sentido que atravessa tanto a ficção quanto a crítica de Piglia/Renzi e o modo como ela se coloca diante do fluxo vital, partindo para tanto da figuração do corpo inerte. "Notas sobre a historicidade de Os diários de Emilio Renzi”, de Júlio Pimentel Pinto, reflete sobre as múltiplas intervenções (estratégias de ordenação, deslocamento, distanciamento) mediante as quais se efetiva o regime de historicidade legível nos Diários.

Integrando, ainda, o núcleo inicial deste Dossiê, o artigo de Miriam Viviana Gárate propõe uma leitura da ficção de origem da escrita "por vir" vinculada à linhagem de Renzi, retrospectivamente encenada no primeiro tomo dos Diários. Gisela Bergonzoni persegue as aparições de um elemento narrativo que perpassa alguns textos desse primeiro tomo dos Diários, enquanto cifra da correspondência entre vida e escrita. Kelvin Falcão Klein esboça uma genealogia possível da figura de escritor, a partir do modo como as imagens são requisitadas especialmente no terceiro tomo dos Diários. "Ricardo Piglia e a tradução: modos de usar", de Livia Grotto, examina o papel da tradução na trajetória de Piglia enquanto editor, tradutor, professor, crítico e ficcionista e suas implicações na emergência de uma genealogia da literatura argentina, bem como da poética do autor.

Os textos que se seguem a esse primeiro conjunto deslocam-se em direção a outros autores e outras literaturas. $O$ primeiro deles estabelece um diálogo sub-reptício com uma experiência decisiva para esse personagem entranhável dos Diários de Renzi, queéo avô Emilio, e com os arquivos deste: a Primeira Guerra Mundial. Situando Dias de Guerra (1930) de Giovanni Comisso no contexto da literatura italiana, Andrea Gialoretto propõe uma leitura da obra desse escritor, que mobiliza materiais diversos no intuito de delinear a genealogia da escrita de suas memórias e de estabelecer relações com um conjunto amplo de registros das experiências dos combatentes italianos. 
Dois artigos exploram as relações entre genealogia e linhagem no âmbito das letras contemporâneas do cone sul: "Pela boca do pai? Tamara Kamenszain e as línguas do judaísmo”, de Adriana Kanzepolsky, que investiga o lugar ocupado pelo "judaico" na poesia de Kamenszain, concebido como uma condição que se herda e que se transmite, "inclusive", assinala a autora, "a contragosto"; e "Bibliotecas de infância na narrativa chilena atual”, de Lorena Amaro, que analisa as cenas de leitura representadas por seis narradores chilenos em relatos recentes, de caráter autobiográfico ou autoficcional, e as conexões destas com uma constelação familiar marcada pela precariedade, assim como com a desarticulação de políticas culturais prévias, levada a cabo pela ditadura militar. Luciene Azevedo, por sua vez, partindo da noção de "estética da iminência" de Néstor Canclini, lê o romance Estação Atocha (2016) do norte-americano Ben Lerner como "laboratório de experimentação intelectual" que oferece ao leitor o processo de sua composição, colocando--se na fronteira do ensaio e do que a autora entende como uma "estética da anotação".

O Dossiê inclui ainda três ensaios voltados para a literatura brasileira. Marcelo Diego lê a contrapelo da crítica estabelecida a presença de Shakespeare em Dom Casmurro ao postular Hamlet, e não Otelo, como a autêntica peça genealógica do romance machadiano. Monica Gama ("O diário de Guimarães Rosa: estudo e diálogo autoral”) e Marcelo Marinho em coautoria com David Lopes da Silva ("Desenredo", de João Guimarães Rosa: prosoema, metapoesia, necrológio prévio ou "autobiografia irracional"?) propõem aproximações diversas da escritura rosiana. O primeiro artigo focaliza o diário escrito por Guimarães Rosa em Paris, detendo-se no exame das considerações do autor sobre diários de outros escritores, sobre os mecanismos de narração de si e sobre a relação dessa autocontemplação com o mundo, no intuito de avaliar como essas reflexões ecoam em crônicas de Rosa e no prefácio de seu último livro; o segundo empreende um "exercício transcriativo" com base no "enredo biopoético" que envolve as três candidaturas do autor para ocupar uma cadeira da ABL, propondo uma leitura de "Desenredo", de Tutameia Terceiras estórias (1967), a partir desse horizonte genealógico.

Por fim, três artigos vinculados ao âmbito da crítica e da teoria francesas encerram o Dossiê. Claudia Amigo Pino retraça a crise vivida por Barthes no final dos anos 1960 e a solução encontrada - um novo tipo de escrita -, a partir do estudo das anotações manuscritas das aulas, em "Da filiação do pesquisador à filiação do escritor: Roland Barthes e o 
seminário da crise intelectual”. Paulo Procopio Ferraz lê as flutuações dos sentidos que Barthes confere à noção de metalinguagem, ao acompanhar suas variações em Mitologias, nos Seminários de preparação do livro Fragmentos de um discurso amoroso e no livro homônimo. Pierre-Ulysse Barranque cartografa as anotações feitas por Baudrillard nos livros que integram sua biblioteca pessoal e em um conjunto de fichas, tendo em vista estabelecer conexões com a produção do intelectual francês.

Registramos, por último, que graças à generosa intermediação de Pedro Meira Monteiro, a seção Documentos deste número de Remate de Males reproduz uma página dos cadernos de Ricardo Piglia depositados Biblioteca Firestone, em Princeton.

Miriam Viviana Gárate (Unicamp) Gisela Bergonzoni (Unicamp) Kelvin Falcão Klein (Unirio)

Recebido: 26/11/2019

Aceito: 26/11/2019

Publicado: 5/12/2019 